\title{
Isolation and characterization of a unique division mutant of Bacillus megaterium
}

\author{
David A. Lach, $\nmid$ Vijay K. Sharma and Patricia S. Vary* \\ Department of Biological Sciences, Northern Illinois University, DeKalb, Illinois 60115, USA
}

(Received 24 August 1989; revised 30 October 1989; accepted 10 November 1989)

\begin{abstract}
A filamentous division mutant, PV302, of Bacillus megaterium QM B1551 was isolated while screening for sporulation-defective mutants after nitrosoguanidine mutagenesis. Both phase-contrast and electron microscopy revealed that the mutant produced small spherical cells as well as filaments. It also accumulated large amounts of poly- $\beta$-hydroxybutyrate. Poly- $\beta$-hydroxybutyrate accounted for $16 \%$ of the dry weight of the mutant strain even after $28 \mathrm{~h}$ growth. In comparison to the parental strain, the division mutant also showed both an inability to sporulate and a reduced growth rate. All these phenotypes transduced together. Revertants gained the ability to sporulate, divide, and grow normally. Transductional mapping of the mutation, designated div-1, established a new linkage group for $B$. megaterium consisting of div-1 and the pyrimidine biosynthesis genes pyrDBCF. The spherical cells were separated from filaments by sucrose gradients and were tested for nucleic acid content and viability. The purified spherical cell fraction contained one-fifth the amount of DNA per mg protein as compared with the filamentous cell fraction and was shown to contain both non-viable minicells and some cells capable of growing after a lag of about $4 \mathrm{~h}$. This suggests that the mutation not only causes defects in septum placement and sporulation, but may possibly affect DNA partitioning.
\end{abstract}

\section{Introduction}

Bacterial cell division is a genetically regulated process that results in the partitioning of a cell by the formation of an equatorial septum. The understanding of this process has largely relied upon the isolation and characterization of several classes of mutations that alter the normal completion of division (for reviews see Donachie et al., 1984; Donachie \& Robinson, 1987; Mendelson, 1982). One class includes mutations which lead to the asymmetric location of cell division near cell pole regions, resulting in minicells (Adler et al., 1967; Reeve et al., 1973). Such division-site-location mutants have been studied in both Bacillus subtilis and Escherichia coli, and different genes responsible for minicell production have been mapped (Bachmann, 1983; Reeve et al., 1973; Reeve, 1979; Van Alstyne \& Simon, 1971) and have been very useful in studying plasmid-coded proteins (Dougan \& Kehoe, 1984; Shivakumar et al., 1979). In addition, a number of minicell-producing mutants of

† Present address: Ecogen, Inc., Langhorne, PA 19047, USA.

Abbreviations: DPA, dipicolinic acid: PHB, poly- $\beta$-hydroxybutyrate. other species have been reported (Forsberg et al., 1970; Setlow et al., 1973; Voros \& Goodman, 1965).

In the genus Bacillus, the question of how the genetic control of cell division is related to the process of sporulation remains for the most part unanswered. Sporulation requires a shift from symmetric to asymmetric division. Hitchins \& Sadoff (1974) proposed that the asymmetric division made during sporulation is a modified cell division. In support of this view, temperature-sensitive division mutants have been described that fail to initiate cell division and sporulation at the restrictive temperature while normal division and sporulation occur at the permissive temperature (Hitchins \& Sadoff, 1974; Miyakawa \& Komano, 1981; Sadie \& Kada, 1985), implying some linkage between the two processes.

In this communication, we describe the isolation and properties of a sporulation-defective, filamentous- and spherical-cell-producing division mutant of Bacillus megaterium QM B1551. Since B. megaterium is proving very useful as a host for cloning foreign DNA (Vary \& Tao, 1988), a minicell mutant would be advantageous in this species. However, we have found that this mutant produces spherical cells which are comprised of both minicells lacking DNA and cells that contain DNA. 


\section{Methods}

Strains, culture conditions and transductions. All B. megaterium strains used in this study are derivatives of strain QM B1551 and are listed in Table 1. Growth conditions, media, and transduction procedures have been described previously (English \& Vary, 1986). Minimal glucose salts media (MC, MCT) and supplemented nutrient broth (SNB) were as described except that minimal medium also contained $6 \mathrm{~g} \mathrm{KH} \mathrm{KO}_{4}$ per litre. For viability studies of the division (Div) mutant, a modified hypertonic RHAF medium (M-RHAF) of Von Tersch \& Carlton (1983) was used in which the sucrose was decreased to $4.5 \%(\mathrm{w} / \mathrm{v})$. For transductional mapping the fitamentous Div- phenotype was screened by picking purified transductants to $0.2 \mathrm{ml} \mathrm{SNB}$ in 96 -well tissueculture plates, and clones were scored after $6-8 \mathrm{~h}$ incubation at $30^{\circ} \mathrm{C}$ using an American Optical Biostar inverted microscope at a magnification of $450 \times$.

Microscopy. All phase-contrast photomicrographs were taken using a Zeiss Standard microscope with Polaroid camera attachment and 665 P/N Polaroid film. Staining of poly- $\beta$-hydroxybutyrate (PHB) inclusions was done with $0.25 \%$ Sudan black B in ethylene glycol. Cultures were grown on SNB agar in a depression slide covered with a coverslip (Reeve et al., 1973) and incubated in moist chambers at $30^{\circ} \mathrm{C}$.

Cell counts, made in a Petroff-Hausser counting chamber, were either of spherical (minicells and coccoid) cells or of filaments. The total cell count included all non-spherical cells (smaller than normal cells, normal cells and long filaments). The majority $(>99 \%)$ of the non-spherical cells in the filamentous cell preparation were a few to several times larger than normal cells. No septa were seen in any of the non-spherical cells except at the point of spherical or minicell attachment. They have therefore been termed 'filaments'. Each filament was counted as one cell.

For electron microscopy, $25 \mathrm{ml}$ cultures were harvested at an $\mathrm{OD}_{660}$ of $0.6-1.0\left(2-5 \times 10^{-7}\right.$ c.f.u. $\left.\mathrm{ml}^{-1}\right)$ by centrifugation at $1480 \mathrm{~g}$ for $10 \mathrm{~min}$ at $4{ }^{\circ} \mathrm{C}$. Cell pellets were then resuspended in $0.1 \mathrm{M}$-sodium cacodylate buffer (pH 7.4), distributed to $1 \mathrm{ml}$ polypropylene Eppendorf tubes and washed by centrifugation for $15 \mathrm{~s}$ at $4{ }^{\circ} \mathrm{C}$ in an Eppendorf Microfuge. The supernatant was then removed and the cell pellets were fixed simultaneously by resuspension in a mixture of $2.5 \%$ (v/v) glutaraldehyde in 0.1 $\mathrm{M}$-sodium cacodylate buffer ( $\mathrm{pH} \mathrm{7.4),2 \%}$ (w/v) aqueous $\mathrm{OsO}_{4}$, and $0.2 \mathrm{M}$-sodium cacodylate buffer $(1: 1: 1$, by vol.) for $4 \mathrm{~h}$ at $4{ }^{\circ} \mathrm{C}$ (Hirsh \& Fedorko, 1968). Cells were then washed three times in $0.1 \mathrm{M}$-sodium cacodylate buffer before being passed through a graded series of $10,30,50,70,90,95$ and $100 \%$ ethanol, ethanol/acetone $(1: 1, v / v)$, and finally pure acetone. Embedding was done in Mollenhauer Epon Araldite resin and polymerization was at $60{ }^{\circ} \mathrm{C}$ for $48 \mathrm{~h}$ (Mollenhauer, 1963). Thin sections were made with an LKB-Huxley mark 2 ultramicrotome using glass knives (LKB KnifeMaker) and were picked up on 400-mesh copper grids. Grids were strained with $2 \%(\mathrm{w} / \mathrm{v})$ uranyl acetate for $10 \mathrm{~min}$ and counterstained with $0.2 \%(\mathrm{w} / \mathrm{v})$ lead citrate for $30 \mathrm{~min}$. The grids were viewed using an Hitachi HS-9 transmission electron microscope operated at $75 \mathrm{kV}$.

Mutant isolation. The filamentous and sporulation-defective phenotype of PV302 was discovered during selection and screening for sporulation-defective mutants. The parental strain, JV42, was grown to an $\mathrm{OD}_{660}$ of 1.0 in SNB, mutagenized with $N$-methyl- $N^{\prime}$-nitro- $N$ nitrosoguanidine $\left(75 \mu \mathrm{g} \mathrm{ml}^{-1}\right.$ for $\left.1 \mathrm{~h}\right)$, diluted in minimal medium and plated for single colonies on SNB agar. The plates were incubated at $25{ }^{\circ} \mathrm{C}$ for $5 \mathrm{~d}$ to allow sporulation. Replica SNB plates were then made. One plate was heated at $80^{\circ} \mathrm{C}$ for $20 \mathrm{~min}$ to kill vegetative cells, while the other plate was untreated. Both replicates were then incubated at $30^{\circ} \mathrm{C}$ for $48 \mathrm{~h}$. Colonies appearing only on the unheated plates were purified on SNB and examined microscopically after an additional heat selection and replica plating.
Table 1. B. megaterium strains used in this study

\begin{tabular}{lll}
\hline \hline Strain & \multicolumn{1}{c}{ Genotype } & \multicolumn{1}{c}{ Source* } \\
\hline QM B1551 & Prototrophic & JCV \\
JV42 & purB3 & JCV \\
JV101 & cysC1 strA3 & JCV \\
PV5 & cysB20 & Garbe et al. (1984) \\
PV43 & cysC21 & Garbe et al. $(1984)$ \\
PV61 & cysC22 strA3 & PVCC \\
PV87 & leuC4 pyrC21 strA3 & PVCC \\
PV88 & leuC4 pyrB23 strA3 & PVCC \\
PV167 & trpB3 cysB24 & PVCC \\
PV184 & trpB3 pyrD24 & PVCC \\
PV236 & metA3 nic-1 & PVCC \\
PV237 & metA3 pyrF25 & PVCC \\
PV302 & purB3 div-1 & This study \\
PV310 & metA3 pyrF26 & PVCC \\
PV320 & purB3 div & This study \\
PV571 & div-1, 7p $\dagger$ & This study \\
\hline \hline
\end{tabular}

* JCV, J. C. Vary, University of Illinois School of Medicine at Chicago; PVCC, P. S. Vary culture collection. All strains are derivatives of QM B1551.

$+7 \mathbf{p}^{-}$, devoid of all seven resident plasmids.

Three spontaneous revertants for the $\mathrm{Div}^{-}$phenotype were isolated independently by differences in colony morphology on SNB plates or by monitoring broth cultures microscopically. Div $^{-}$strains became translucent because of lysis after $48 \mathrm{~h}$ on SNB, whereas revertants and the parental strain did not.

Mutant characterization. PHB was determined by removing samples $(25$ or $50 \mathrm{ml})$ from $800 \mathrm{ml}$ cultures grown in SNB at $30^{\circ} \mathrm{C}$ in 2.81 Fernbach flasks at 350 r.p.m. at the indicated times and centrifuging at $4340 \mathrm{~g}$ for $10 \mathrm{~min}$ at $4{ }^{\circ} \mathrm{C}$. Cell pellets were frozen at $-70^{\circ} \mathrm{C}$ and lyophilized. Dry weight determinations ( $\mathrm{mg}$ cells per $\mathrm{ml}$ culture) were made to the nearest $0.1 \mathrm{mg}$. Cell suspensions of $1 \mathrm{mg} \mathrm{ml}^{-1}$ were made in distilled water, and $0.2 \mathrm{ml}$ samples were extracted and assayed for PHB by a disk assay modification (Ward \& Dawes, 1973) of the method of Law \& Slepecky (1961), which measures the conversion of PHB to crotonic acid. PHB was used as a standard. Dipicolinic acid (DPA) was measured colorimetrically by the method of Janssen et al. (1958) as modified by Rotman \& Fields (1968), using dipicolinic acid as a standard.

Isolation of minicells. A modification of the method of Reeve et al. (1973) was used. Cells were grown in modified RHAF broth with shaking (250 r.p.m.) to an $\mathrm{OD}_{660}$ of $0 \cdot 8-1 \cdot 0$. The culture was chilled on ice and centrifuged in a Sorvall RC5B centrifuge at $367 \mathrm{~g}$ at $4{ }^{\circ} \mathrm{C}$ for $5 \mathrm{~min}$. The pellet, which contained filaments and normal cells, was saved for a subsequent sucrose gradient as described for spherical cells below. The supernatant was removed carefully and centrifuged at $4080 \mathrm{~g}$ for $8 \mathrm{~min}$. This pellet, enriched in spherical cells, was resuspended in MCT and 2-3 ml samples were layered on a $35 \mathrm{ml}, 5-$ $35 \%$ sucrose gradient and centrifuged at $1600 \mathrm{~g}$ at $4{ }^{\circ} \mathrm{C}$ in an IEC tabletop centrifuge equipped with a swinging-bucket rotor. A very diffuse band in the middle part of the tube could be visualized by holding the tube against a fluorescent light in a dark-room. When examined under the phase-contrast microscope, this band contained spherical cells and some contaminating filaments. The pellet at the bottom contained only filamentous cells. The large diffuse band was harvested and pelleted by centrifugation at $13218 \mathrm{~g}$ for $15 \mathrm{~min}$ and the cells were washed once with MCT. A $2 \mathrm{ml}$ sample was again layered on a $5-35 \%$ sucrose gradient and centrifuged as before. A sharper band was obtained in the middle of the tube. This band was harvested, pelleted, and subjected to two more sucrose-gradient centrifugations to obtain spherical cells 
virtually free of any detectable contaminating filamentous cells for viability studies, or it was washed three times with $0.85 \%$ saline and the cells (containing $<1 \%$ filaments) were used in the DNA, RNA and protein assays. The filamentous cell pellet was passed through a single sucrose-gradient centrifugation and was washed three times either with MCT for viability studies or with $0.85 \%$ saline for DNA, RNA and protein assays.

Determination of viability, and of DNA, RNA and protein. The purified spherical cells and filamentous cells were inoculated into $20-30 \mathrm{ml}$ prewarmed M-RHAF broth to an $\mathrm{OD}_{660}$ of $0 \cdot 1-0.2$. Cultures were incubated at $37^{\circ} \mathrm{C}$ with shaking at 250 r.p.m. and $\mathrm{OD}_{660}$ was monitored. At indicated times, $0.5 \mathrm{ml}$ of each culture was removed and used both for microscopic total cell counts and for assay of viability, which was done by plating appropriate dilutions on SNB plates. Total cell counts were obtained by counting a $10 \mu$ sample from an appropriate dilution in a Petroff-Hausser counting chamber according to the manufacturer's instructions. Preparation of cells for DNA, RNA and protein assays was as described by Reeve et al. (1973). DNA was assayed by the Schneider (1957) variation of the diphenylamine reaction using calf thymus DNA as the standard. Protein was assayed by the Lowry method, using bovine serum albumin as the standard. RNA was assayed by the orcinol procedure of Schneider (1957) with yeast tRNA as the standard. Giemsa staining of whole cells for DNA was done by the method of Murray et al. (1950) with the exception that the cells were first heat-fixed on slides.

Characterization of pyrimidine mutants. Uracil-requiring strains were grown on SNB agar plates overnight at $30^{\circ} \mathrm{C}$ and replica plated to minimal salts agar with and without the following concentrations of intermediates: uracil, uridine 5 '-monophosphate, L-aspartic acid or carbamoyl phosphate $\left(50 \mu \mathrm{g} \mathrm{ml}^{-1}\right)$; orotic acid $\left(120 \mu \mathrm{g} \mathrm{ml}^{-1}\right)$; orotidine $5^{\prime}$-monophosphate $\left(250 \mu \mathrm{g} \mathrm{m}^{-1}\right)$, L-dihydroorotic acid $\left(300 \mu \mathrm{g} \mathrm{ml}^{-1}\right)$ or carbamyl-DL-aspartic acid $\left(350 \mu \mathrm{g} \mathrm{ml}^{-1}\right)$.

Chemicals. All chemicals were obtained from Sigma unless otherwise indicated.

\section{Results}

\section{Isolation and characterization of the division mutant}

Approximately 1000 colonies were screened for asporogeny by heat sensitivity following mutagensis as described in Methods. After purification, six mutants were obtained that failed to form heat-resistant colonies after $48 \mathrm{~h}$ growth on SNB plates. One of these putative sporulation mutants, PV302, was characterized further because of its filamentous growth and other interesting properties.

The rate of growth exhibited by PV302, determined by increase in dry weight, was compared to the parental strain JV42. Generation times of 85 and $56 \mathrm{~min}$ were obtained for the mutant and the parental strain, respectively. Generation times of 58 and $90 \mathrm{~min}$ were obtained, based on increase in $\mathrm{OD}_{660}$, for JV42 and PV302 respectively in M-RHAF broth (data not shown). Thus the parental strain grows faster than the mutant in either medium.

Phase-contrast microscopy of PV302 revealed various morphological differences from the parental strain, including filamentous growth and abnormal septation, and the accumulation of large PHB inclusions during growth of the mutant strain. Mutant cells, ranging from 30 to $100 \mu \mathrm{m}$ in length, were often observed to have spherical 'minicells' usually located at polar regions of the filament (Fig. 1a). Div ${ }^{-}$transductants also displayed a filamentous, 'minicell'-forming phenotype (Fig. 1c) and were also defective in sporulation and accumulated PHB. Three independently isolated $\mathrm{Div}^{-}$revertants, detected by colony morphology, exhibited wild-type morphology (Fig. 1d), growth and sporulation.

Transmission electron micrographs of thin sections of mid-exponential-phase cells revealed that the placement of septa in PV302 was irregular in comparison with the parental strain. Asymmetric septa resulted in the formation of small, spherical cells (Fig. 2b,c). Abnormal accumulation of electron-dense cell wall material was also noticeable at some sites of septum formation (Fig. 2c). Spherical cells were sometimes observed in tandem (not shown). Only symmetric septal placement was seen in the parental culture sample (Fig. 2a).

As mentioned above, PV 302 also accumulated numerous large PHB inclusions throughout growth. During exponential growth of wild-type cells, small PHB inclusions were evident (see Fig. 2a), but these became smaller and less noticeable after the onset of sporulation. In contrast, the inclusions were very evident in electron micrographs of the mutant cells (Fig. $2 b, c$ ) and were visualized by light microscopy as phase-bright or Sudanblack-staining bodies (Fig. 1e,f). Accumulation of PHB and the asporogeny of the mutant strain were measured quantitatively by growing both mutant and parental cultures in SNB and assaying for PHB and the sporespecific compound DPA as described in Methods. The results (Fig. 3) indicated that after $28 \mathrm{~h}$ growth the mutant strain contained up to $260 \mu \mathrm{g} \mathrm{PHB} \mathrm{ml} \mathrm{m}^{-1}(16 \%$ of dry weight) and only minimal levels of DPA. In contrast, the amount of PHB decreased from $235 \mu \mathrm{g} \mathrm{ml}^{-1}$ at $6 \mathrm{~h}$ (18\% of dry weight) to non-detectable levels at $28 \mathrm{~h}$ in the parental strain, while the cellular DPA level increased as spores were formed.

\section{Transductional mapping}

In order to map the mutation responsible for the $\mathrm{Div}^{-}$ phenotype, several available auxotrophic mutants wereused as recipients in two-factor crosses with phage MP13 lysates of the div-1 mutant. Several previously uncharacterized uracil-requiring mutants from our laboratory stock collection were grown on intermediates of pyrimidine biosynthesis to tentatively assign the specific pyr gene defects of these mutants according to the scheme of Potvin et al. (1975), as shown in Table 2. Other auxotrophic mutations known to be linked to division site loci in $B$. subtilis were also tested for cotransduction 

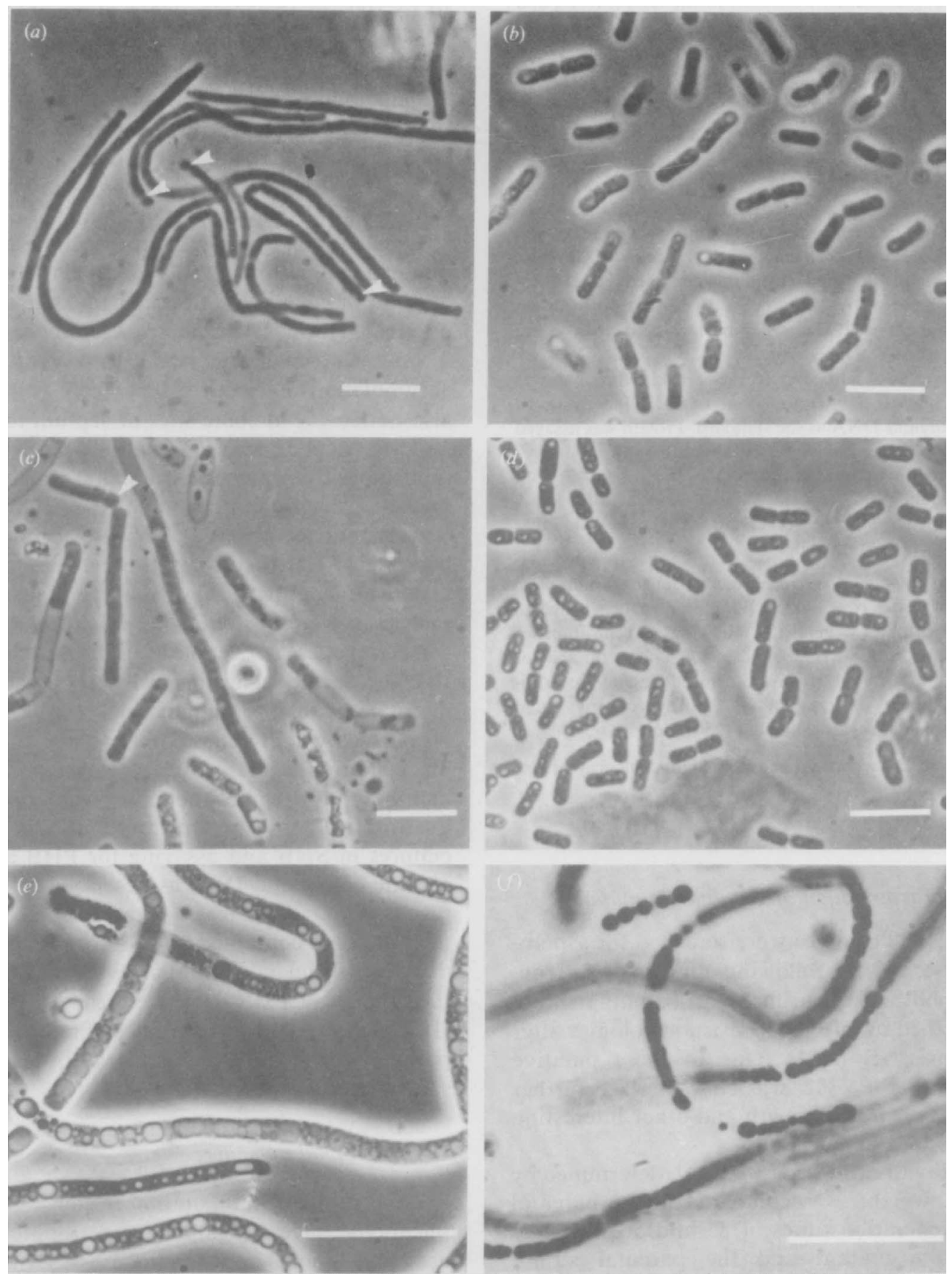

Fig. 1. Phase-contrast microscopy of PV302, JV42 and revertant strains. (a) PV302 (div-I) showing filamentous growth and spherical cells (arrows). (b) JV42 parental strain. (c) A typical Div ${ }^{-}$transductant with spherical cell (arrow), filamentous growth and PHB inclusions. (d) PV320, a spontaneous Div ${ }^{+}$revertant of PV302. (e) PV302 exhibiting accumulation of PHB after 24 h. ( $f$ ) Sudan black stain of PHB inclusions in PV302. Bars, $10 \mu \mathrm{m}$. 

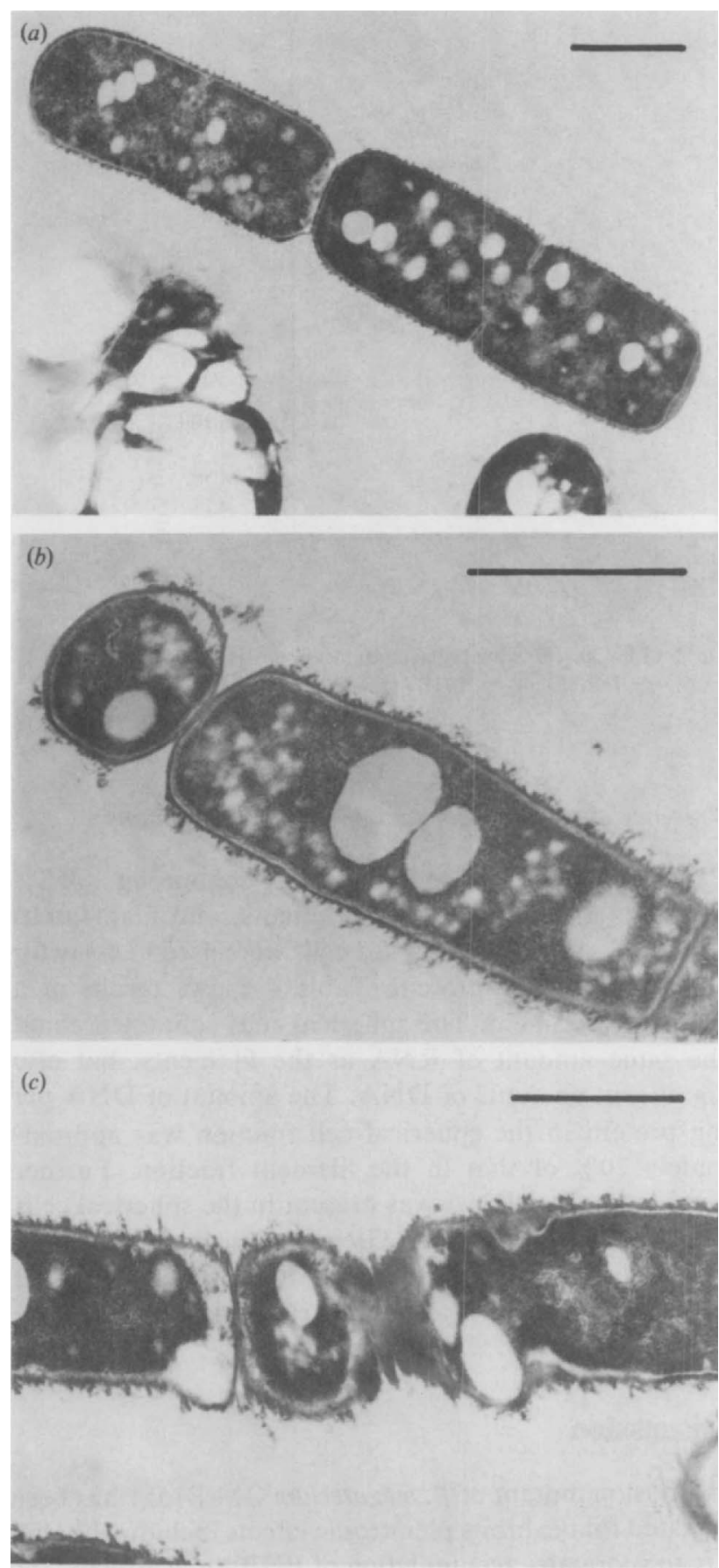

Fig. 2. Transmission electron microscopy of $\mathrm{PV} 302$ and its parent. (a) JV42, parent of PV302. (b) PV302, showing spherical cell. (c) PV302, showing centrally located spherical cell with abnormal accumulation of cell wall material. Bars, $1 \mu \mathrm{m}$.

with the div-1 mutation. No cotransduction was found when PV5, PV43, PV61, PV87, PV167, PV236 and JV101 were used as recipients. The div-1 locus was therefore not linked to leuC, nic-1, cysB or cysC, but was
Table 2. Characterization of pyr mutants

Growth on*:

Locus

Strain MC CP + A CAA DHO OA OMP UMP Ura designation

\begin{tabular}{llllllllll}
\hline PV87 & - & - & - & + & + & - & + & + & pyrC21 \\
PV88 & - & - & + & + & + & + & + & + & pyrB23 \\
PV184 & - & - & - & - & + & - & + & + & pyrD24 \\
PV237 & - & - & - & - & - & - & + & + & pyrF25 \\
PV310 & - & - & - & - & - & - & + & + & pyrF26
\end{tabular}

* Abbreviations: CP, carbamoyl phosphate; $A$, aspartic acid; CAA, carbonyl aspartic acid; DHO, dihydroorotic acid; OA, orotic acid; OMP, orotidine 5'-monophosphate; UMP, uridine 5'-monophosphate; Ura, uracil. +, Growth after $24 \mathrm{~h} ;-$, no growth.

linked to pyr loci, as shown in Table 3. Based on these data, the tentative order is: div-1-pyrD24-(pyrB23pyrC21)-(pyrF25-pyrF26).

\section{Isolation and viability of spherical cells}

In preliminary experiments, an increase in viable cells in the spherical cell fraction was observed after a long lag time. A solution to three problems had to be found before accurate viability and DNA determinations could be made. First, since PV302 also contained the seven resident plasmids of $B$. megaterium QM B1551, it was necessary to transfer the div-1 mutation by cotransduction into a pyr mutant of the plasmidless strain PV361 (Sussman et al., 1989) in order to ascertain whether or not the spherical cells were true non-viable minicells devoid of DNA. Second, both filaments and spherical cells exhibited greatly decreased viability when grown in SNB broth and plated on SNB agar (as much as 10-4 difference between microscopic total cell counts and viable counts), which made it impossible to get a true determination of viability from either fraction. However, the growth of the filamentous or spherical cell fraction in M-RHAF broth and subsequent plating on SNB agar was found to give efficiencies of plating of $10 \%$ (total cell count/viable cell count), so this procedure was used for viability experiments. Thus, it appears that the cells might have continually died during growth in SNB broth so that subsequent plating on SNB agar produced poor viable counts. On the other hand, when grown in M-RHAF broth, the cells appeared healthy and produced higher viable counts when plated on SNB agar. A third difficulty was that the spherical cell fractions were found to have $3-9 \%$ contaminating filaments after one sucrose gradient. Four sucrose gradients decreased the filaments to undetectable amounts microscopically (Fig. 4a). Using this fraction as inoculum, cells were grown in M-RHAF broth and sampled at designated 


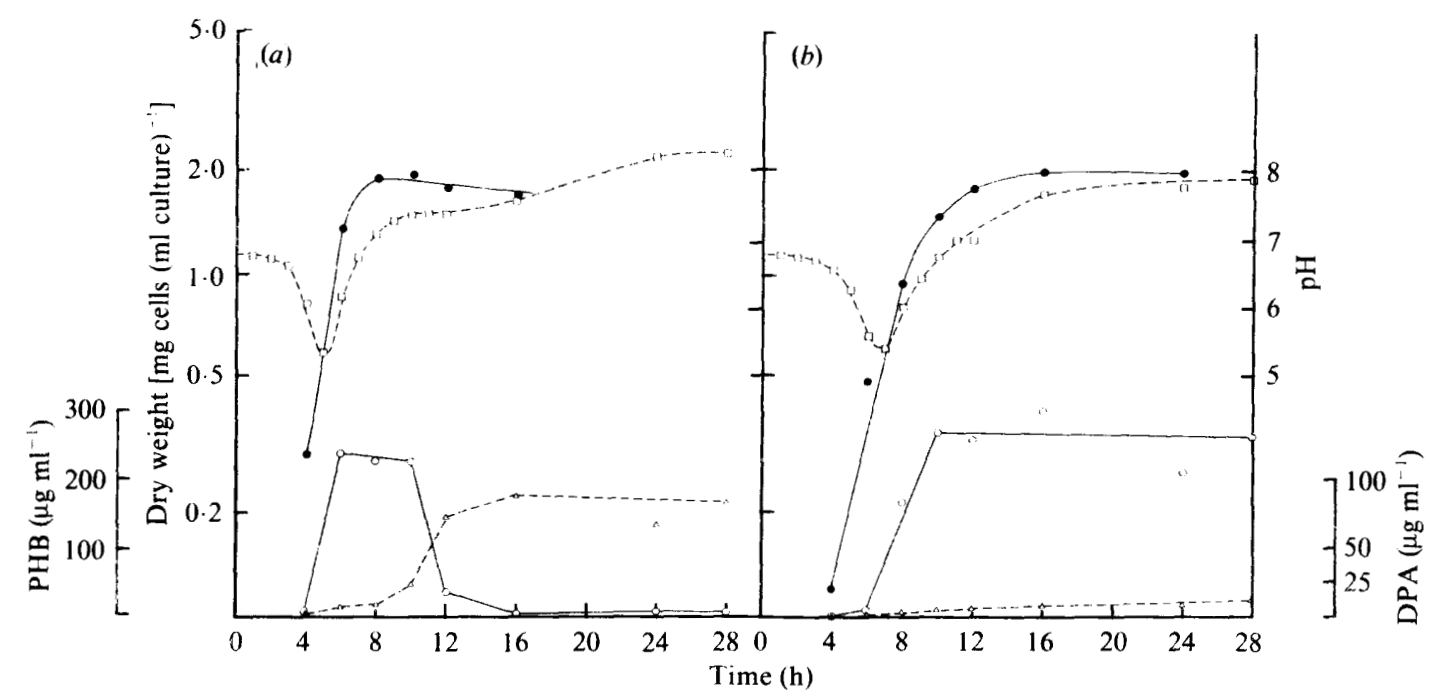

Fig. 3. Comparison of growth and production of PHB and DPA in JV42 (a) and PV302 (b), showing accumulation of PHB and lack of production of spores (as monitored by. DP.A production) in the mutant. $\triangle--\triangle$, DPA; O-O, PHB; $-\bullet$, dry weight; $\square--\square$, $\mathrm{pH}$.

Table 3. Cotransductional mapping of the div-1 locus

All crosses were performed as described in Methods, with strain PV302 (div-1) as donor.

\begin{tabular}{lcc}
\hline \hline \multicolumn{1}{c}{ Recipient } & $\begin{array}{c}\text { No. unselected/ } \\
\text { no. selected* }\end{array}$ & $\begin{array}{c}\text { Percentage } \\
\text { cotransduction }\end{array}$ \\
\hline PV184 (pyrD24) & $199 / 1230(6)$ & 16 \\
PV237 (pyrF25) & $71 / 939(2)$ & 7 \\
PV310 (pyrF26) & $65 / 791(2)$ & 8 \\
PV87 (pyrC21) & $128 / 1310(3)$ & 10 \\
PV88 (pyrB23) & $201 / 1864(5)$ & 11 \\
\hline \hline
\end{tabular}

* Numbers in parentheses indicate the number of crosses.

intervals for total and viable numbers of minicells and filamentous cells. The filamentous cell fraction was always run as a control. The data in Fig. 5 show that filaments did appear among the spherical cells and increased after a lag of about $4 \mathrm{~h}$. The increase in filaments paralleled the increase in viability, while the number of minicells stayed constant (as determined by microscopic counts). Fig. 4(b) shows the spherical cell fraction after $7 \mathrm{~h}$ incubation: many filaments are present. The fast doubling times (about $18 \mathrm{~min}$ ) observed in the filamentous and spherical cell fraction cannot be assumed as true doubling times, due to the filamentous nature of the strain. Since growing PV302 cultures exhibit spherical, non-spherical, and filamentous cells of variable length, and these cells in turn form chains of variable length, it is possible that the fast doubling times observed are due to the fragmentation of chains of cells into individual cells.

\section{Presence of nucleic acids in spherical cell fractions}

Purified fractions of spherical cells, containing $<0.8 \%$ filaments after two sucrose gradients, and filamentous cell fractions free of spherical cells were used to assay for RNA, DNA and protein. Table 4 shows results of a typical experiment. The spherical cells contained about the same amount of RNA as the filaments, but also significant amounts of DNA. The amount of DNA per $\mathrm{mg}$ protein in the spherical cell fraction was approximately $20 \%$ of that in the filament fraction. Further verification that DNA was present in the spherical cells was made by staining with Giemsa stain as shown in Fig. $4(c)$. Cells with and without DNA were observed as well as some that seemed to have variable amounts.

\section{Discussion}

A division mutant of B. megaterium QM B1551 has been isolated that exhibits pleiotropic effects including inability to sporulate, accumulation of PHB, slow growth, and formation of both filaments and spherical cells. The division defect seems to be in the placement of the cell septum, rather than initiation of septum formation, since most spherical cells were observed at the ends of filaments, but some were found in tandem and between filamentous cells. A defect in positioning of cell septa is consistent with the morphology reported by Reeve et al. (1973) of $\operatorname{divIVA}$ and $\operatorname{divIVB}$ mutants in $B$. subtilis. Mapping of the div-1 locus placed it near pyrDBCF, consistent with what has been found in $B$. subtilis for 

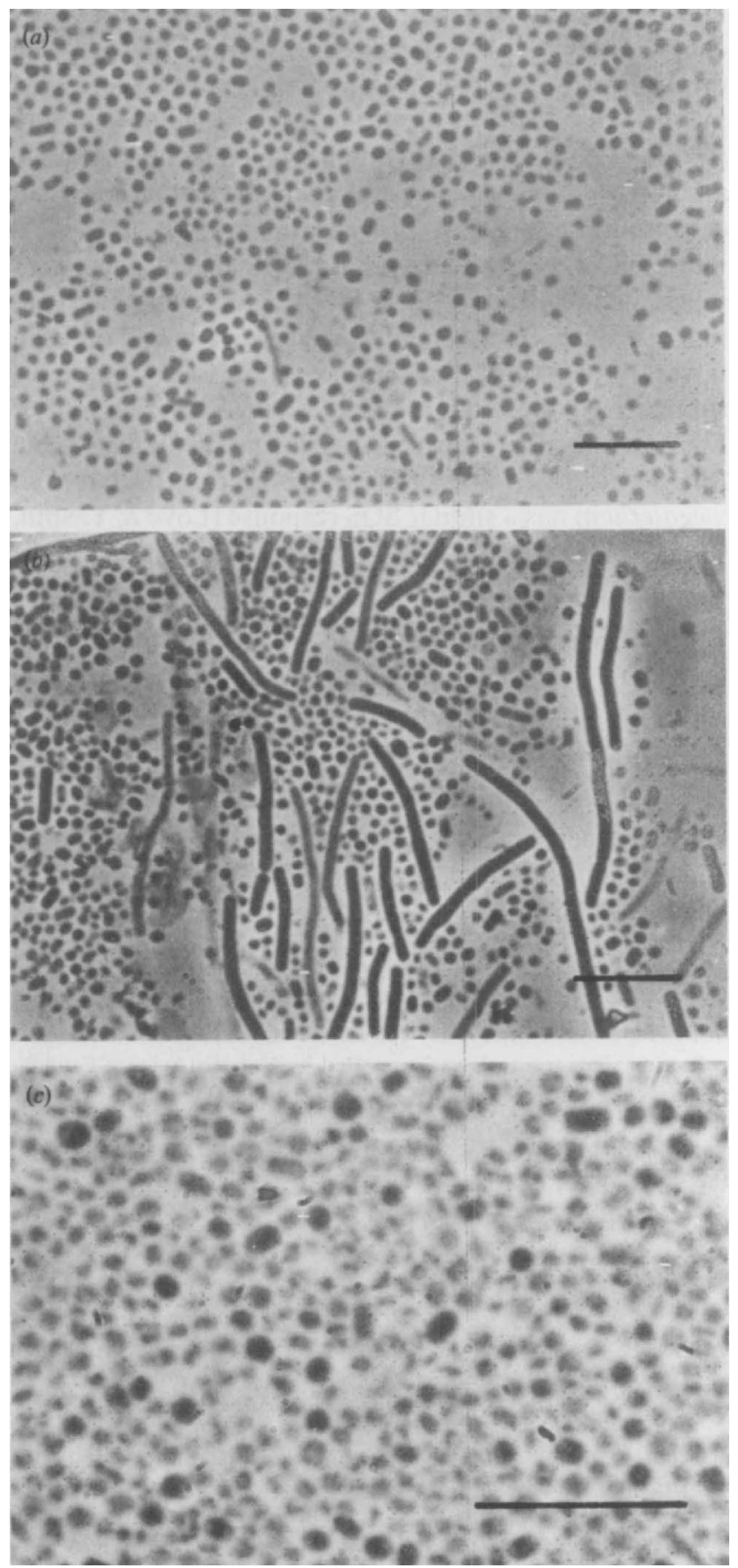

Fig. 4. Spherical cell fraction: after four sucrose gradients (a), after subsequent growth in SNB for $7 \mathrm{~h}(b)$, and stained with Giemsa stain for DNA (c). Bars, $10 \mu \mathrm{m}$.

divIVA (Mendelson, 1982; Reeve et al., 1973; Van Alstyne \& Simon, 1971). In B. subtilis, the divI mutation, which causes a defect in initiation of septum formation (no septa can be seen by electron microscopy) (Mendelson, 1982) is also present near pyr. However, the

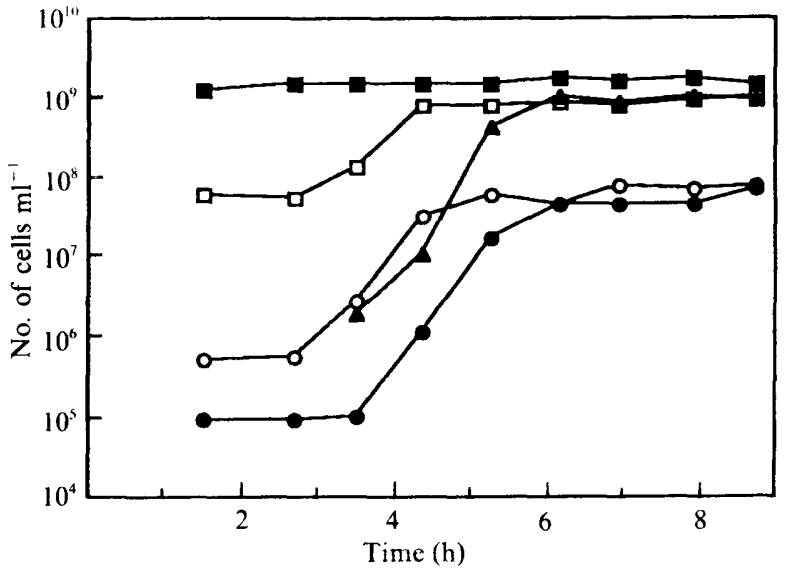

Fig. 5. Viability of preparations of isolated spherical and filamentous cells. Open symbols represent the total microscopic cell count $(\square)$ and the viable cell count $(O)$ in the filamentous cell fraction from a sucrose gradient as described in Methods. Filled symbols represent the total microscopic number of spherical cells $(\boldsymbol{D})$ and filamentous cells $(\boldsymbol{A})$, and the viable cell count $(O)$ within the spherical cell fraction after four sucrose gradients.

Table 4. Protein and nucleic acid content of the two cell fractions

Purified filament and spherical cell fractions were prepared and assayed for nucleic acids and protein as described in Methods.

\begin{tabular}{lcccc}
\hline \hline & $\begin{array}{c}\text { Protein } \\
(\mathrm{mg} \text { per } \\
\text { Cell type }\end{array}$ & $\begin{array}{c}\text { RNA } \\
(\mu \mathrm{g} \text { per }\end{array}$ & $\begin{array}{c}\text { DNA } \\
(\mu \mathrm{g} \text { per }\end{array}$ & $\begin{array}{c}\text { DNA } \\
(\mu \mathrm{g} \text { per }\end{array}$ \\
\hline Filaments & 529 & 162 & 27 & 0.05 \\
Spherical cells & 973 & 367 & 14 & 0.01 \\
\hline \hline
\end{tabular}

morphology, growth characteristics and chromosomal location of the div- 1 mutation of $B$. megaterium resemble the phenotype and position of the $\operatorname{div} I V A$ locus of $B$. subtilis with the exception that the div- $I$ defect gives rise to both minicells and coccoid, or DNA-containing cells. Genetic position as a verification of a mutant gene must be used with caution since several differences in gene positions have been observed between $B$. megaterium and B. subtilis (Garbe et al., 1984; Sussman et al., 1989). It cannot be stated at this time whether $\operatorname{div}-1$ is the equivalent of $\operatorname{div} I V A$. It should also be noted that until now, $B$. subtilis had been the only bacterium reported to have the pyr loci clustered (Potvin et al., 1975).

Pleiotropic effects have been observed in several Bacillus division mutants (Hitchins \& Sadoff, 1974; Miyakawa \& Komano, 1981; Sadie \& Kada, 1985). In $B$. megaterium, a filamentous but non-minicell mutant, TH14, was reported to be weakly oligosporogenous, with revertants that were $\mathrm{Spo}^{+}$(Hitchins \& Sadoff, 1974). Yet 
minicell mutants in $B$. subtilis showed normal sporulation (Coyne \& Mendelson, 1974), in contrast to both the $B$. megaterium div-1 mutant reported here and the TH14 mutant isolated by Hitchins \& Slepecky (1969). Either different loci are involved, or the two species exhibit differences in regulation of sporulation, of which we have some recent evidence (Shivakumar et al., 1989). The pleiotropic effects of the div- 1 mutation, including PHB accumulation, $\mathrm{Spo}^{-}$phenotype, minicell formation, and slow growth, have all been observed in transductants. This observation, with the further evidence that spontaneous revertants were $\mathrm{Div}^{+}, \mathrm{Spo}^{+}$, and normal in PHB production, strongly suggests that the defect in positioning of septa due to the div-1 mutation caused all the phenotypes observed. It also supports the observations of Hitchins \& Slepecky (1969) that division and sporulation are linked in Bacillus spp.

The accumulation of PHB in the div- 1 mutant of $B$. megaterium may be a direct result of the inability to sporulate, since PHB has been reported to be the energy source used in this species for sporulation (Slepecky \& Law, 1961). The pattern of PHB production in the parent JV42, in which PHB decreases during sporulation, supports this conclusion. Under our conditions of growth, a maximal PHB level of $18 \%$ was reached in the parental strain on SNB, whereas PHB was still increasing in the mutant at $28 \mathrm{~h}$. Macrae \& Wilkinson (1958) reported that PHB levels of up to $20-40 \%$ of cell dry weight could be obtained in $B$. megaterium grown on acetate.

Minicell-producing strains of $E$. coli and B. subtilis have proven useful in the analysis of proteins produced by plasmids and bacteriophages because minicells are devoid of chromosomal DNA. However, the seven resident plasmids of $B$. megaterium (Kieselburg et al., 1984) precluded the use of PV 302 for studies on DNA content of the spherical cells because plasmids have been shown to segregate preferentially into minicells in $B$. subtilis (Shivakumar et al., 1979). We therefore transduced the mutation into a plasmidless strain, then separated the cell types on sucrose gradients and tested their viability, and DNA, RNA and protein content. It became evident that even in highly purified fractions, there were viable cells present that contained DNA and were capable of producing filamentous cells. This mutation, therefore, produces both minicells (devoid of all DNA) and coccoid cells (containing DNA), and these could not be separated after four sucrose gradients. The fraction of viable cells was very low since it did not increase at the expense of total minicell counts. However, minicells were also being produced during growth of the filaments, so accurate measurement of 'old' vs 'new' minicells could not be made. The presence in the spherical cell fraction of at least one-fifth the amount of
DNA (when no detectable filaments were present) as compared with the filamentous fraction, the long lag time before any detectable filaments could be observed in the spherical cell fraction upon incubation, and staining that showed cells which seemed to have variable amounts of DNA, suggest that many of the spherical cells containing DNA may be non-viable. The div-1 mutation may, therefore, affect both the placement of septa and the partitioning of DNA, which should be very interesting for future study. Recent work in cell division is very interesting. Donachie \& Robinson (1987) have summarized the evidence that shows that coupling of DNA replication with cell division is mediated by the SOS response in E. coli. B. subtilis (and so probably $B$. megaterium) has a similar SOS response (Love \& Yasbin, 1986). Moreover, Mulder \& Woldringh (1989) have recently shown in $E$. coli that nucleoid replication influences septum placement in filamentous cells that produce DNA-free progeny. Research on the genetics of division in Bacillus is obviously in its infancy, but it holds promise for understanding the complex genetics of division in the Gram-positive bacteria. This mutant is the first reported in $B$. megaterium to be defective in septum placement, and its phenotype suggests possible linkages of septum placement to DNA partitioning and sporulation.

We thank Dian Molsen for advice and guidance with the electron microscopy and James Vary for advice and access to his culture collection. This research was supported by National Science Foundation grants DMB8208323 and DMB8607259(PSV) and by BRSG S07 RR07176 awarded by the Biomedical Support Grant Program, Division of Research Resources, the National Institutes of Health.

\section{References}

Adler, H. I., Fisher, W. D., Cohen, A. \& Hardigree, A. A. (1967). Miniature Escherichia coli cells deficient in DNA. Proceedings of the National Academy of Sciences of the United States of America 57, 321326.

BACHMANN, B. (1983). Linkage map of Escherichia coli K12, edition 7 . Microbiological Reviews 47, 180-230.

Coyne, S. I. \& Mendelson, N. H. (1974). Clonal analysis of cell division in the Bacillus subtilis divIVB-1 minicell-producing mutant. Journal of Bacteriology 118, 15-20.

DONACHIE, W. D. \& RoBINSON, A. C. (1987). Cell division: parameters values and process. In Escherichia coli and Salmonella typhimurium: Cellular and Molecular Biology. pp. 1578-1593. Edited by F. C. Neidhardt, J. L. Ingraham, K. B. Low, B. Magasanik, M. Schaecter \& H. E. Umbarger. Washington, DC: American Society for Microbiology.

Donachie, W. D., Begg, K. J. \& Sullivan, .. N. F. (1984). Morphogenes of Escherichia coli. In Microbial Development, pp. 2762. Edited by R. Lasick \& L. Shapiro. Cold Spring Harbor, NY: Cold Spring Harbor Laboratory.

DougAN, G. \& KeHOE, M. (11984). The minicell system as a method for studying expression from plasmid DNA. Methods in Microbiology 17, 233-258. 
ENGLISH, J. D. \& VARY, P. S. (1986). Isolation of recombinationdefective and UV-sensitive mutants of Bacillus megaterium. Journal of Bacteriology 165, 155-160.

Forsberg, C. W., Costerton, J. W. \& Macleod, R. A. (1970). Separation and localization of cell wall layers of a gram-negative bacterium. Journal of Bacteriology 104, 1338-1353.

Garbe, J. C., Hess, G. F., Franzen, M. A. \& Vary, P. S. (1984). Genetics of leucine biosynthesis in Bacillus megaterium QM B1551. Journal of Bacteriology 157, 454-459.

HIRSH, J. G. \& FEDORKO, M. F. (1968). Ultrastructure of human leukocytes after simultaneous fixation with glutaraldehyde and osmium tetroxide and 'post fixation' in uranyl acetate. Journal of Cell Biology 38, 615-627.

HrtchINS, A. D. \& SADOFf, H. L. (1974). Properties of a thermosensitive asporogenous filamentous mutant of Bacillus megaterium. Journal of Bacteriology 118, 1167-1175.

Hitchins, A. D. \& SlePECKY, R. A. (1969). Bacterial sporulation as a modified procaryotic cell division. Nature, London 223, 804-807.

JansSen, F. A., Lund, A. J. \& ANDERSON, L. E. (1958). Colorimetric assay for dipicolinic acid in bacterial spores. Science 127, 26-27.

Kieselburg, M. K., Weickert, M. \& VARY, P. S. (1984). Analysis of resident and transformant plasmids in Bacillus megaterium. Biotechnology 2, 254-259.

LAW, J. H. \& SLEPECKY, R. A. (1961). Assay of poly- $\beta$-hydroxybutyrate. Journal of Bacteriology 82, 33-36.

LOVE, P. E. \& YASBIN, R. E. (1986). Induction of the Bacillus subtilis SOS-like response by Escherichia coli RecA protein. Proceedings of the National Academy of Sciences of the United States of America 83, 5204-5208.

Macrae, R. M. \& Wilkinson, J. F. (1958). Poly- $\beta$-hydroxybutyrate metabolism in washed suspensions of Bacillus cereus and Bacillus megaterium. Journal of General Microbiology 19, 210-222.

MENDELSON, N. H. (1982). Bacterial growth and division: genes, structures, forces, and clocks. Microbiological Reviews 46, 341-375.

MiYakaWa, Y. \& Komano, T. (1981). Study on the cell cycle of Bacillus subtilis using temperature-sensitive mutants. I. Isolation and genetic analysis of the mutants defective in septum formation. Molecular and General Genetics 181, 207-214.

MollenhaueR, H. H. (1963). Plastic embedding mixtures for use in electron microscopy. Stain Technology 39, 111-114.

MULDER, E. \& WOLDRINGH, C. L. (1989). Actively replicating nucleoids influence positioning of division sites in Escherichia coli filaments forming cells lacking DNA. Journal of Bacteriology 171, 4303-4314.

Murray, R. G. E., Gillen, D. H. \& Heagy, F. C. (1950). Cytological changes in Escherichia coli produced by infection with phage T2. Journal of Bacteriology 59, 603-615.
Potvin, B. W., Kelleher, R. J., JR \& Gooder, H. (1975). Pyrimidine biosynthetic pathway of Bacillus subtilis. Joumal of Bacteriology 123, 604-615.

REEVE, J. (1979). Use of minicells for bacteriophage-directed polypeptide synthesis. Methods in Enzymology 68, 493-503.

Reeve, J. N., Mendelson, N. H., CoYne, S. I., Hallock, L. L. \& CoLE, R. M. (1973). Minicells of Bacillus subtilis. Journal of Bacteriology 114, 860-873.

RotMAN, Y. \& FIELDS, M. L. (1968). A modified reagent for dipicolinic acid analysis. Analytical Biochemistry 22, 168-172.

SADIE, Y. \& KADA, T. (1985). Bacillus subtilis gene involved in cell division, sporulation, and exoenzyme secretion. Journal of Bacteriology 163, 648-653.

SCHNEIDER, W. C. (1957). Determination of nucleic acids in tissues by pentose analysis. Methods in Enzymology 3, 680-682.

Setlow, J. K., Boling, M. E., Allison, D. P. \& Beattie, K. L. (1973) The relationship between prophage induction and transformation in Haemophilis influenzae. Journal of Bacteriology 115, 153-161.

Shivakumar, A. G., Hahn, G. J. \& Dubnau, D. (1979). Studies on the synthesis of plasmid-coded proteins and their control in Bacillus subtilis minicells. Plasmid 2, 279-289.

Shivakumar, A. G., Vanags, R. I., Wilcox, D. R., Katz, L., Vary, P. S. \& Fox, J. L. (1989). Gene dosage effect on the expression of the delta-endotoxin genes of Bacillus thuringiensis subsp. kurstaki in Bacillus subtilis and Bacillus megaterium. Gene 79, 21-31.

SLEPECKY, R. A. \& LAW, J. H. (1961). Synthesis and degradation of poly- $\beta$-hydroxybutyric acid in connection with sporulation of Bacillus megaterium. Journal of Bacteriology 82, 37-42.

Sussman, M. D., Vary, P. S., Hartman, C. \& Setlow, P. (1989). Integration and mapping of Bacillus megaterium genes which code for small, acid-soluble spore proteins and their protease. Journal of Bacteriology 170, 4942-4945.

VARY, P. S. \& TAO, Y.-P. (1988). Development of genetic methods in Bacillus megaterium. In Genetics and Biotechnology of Bacilli II., pp. 403-408. Edited by J. A. Hoch \& A. T. Ganesan. San Diègo: Academic Press.

Van ALsTYNe, D. \& Simon, M. I. (1971). Division mutants of Bacillus subtilis: isolation and PBS1 transduction of division-specific markers. Journal of Bacteriology 108, 1366-1379.

of Bacillus megaterium. Journal of Bacteriology 155, 872-877.

VoRos, J. \& GoOdMAN, R. N. (1965). Filamentous forms of Erwinia amylovora. Phytopathology 55, 876-879.

WARD, A. C. \& DAWES, E. A. (1973). A disk assay for poly- $\beta$ hydroxybutyrate. Analytical Biochemistry 52, 607-613. 